\title{
$\mathrm{RA}$ 股に対し骨移植単独または水酸化アパタイトを併用して 臼蓋底補強を行った Bipolar 型人工骨頭置換術の検討
}

$\begin{array}{cccccc}\text { 琉球大学整形外科 } & & & & \\ \text { 富 山 } & & \text { 聡·永 } & \text { 山 } & \text { 盛 } & \text { 隆 } \\ \text { 濱 崎 } & \text { 直 } & \text { 人·森 } & & \text { 諭 } & \text { 史 } \\ \text { 吉 川 } & \text { 朝 } & \text { 昭·金 } & \text { 谷 } & \text { 文 } & \text { 則 } \\ \text { 茨 木 } & \text { 邦 } & \text { 夫 } & & & \\ \text { 沖縄整肢療護園 } & & & & & \\ \text { 仲宗根 } & \text { 聡 } & & & \end{array}$

\section{Acetabular Reconstruction for RA Hip with Bone Graft Alone or Bone Graft with Hydroxyapatite}

by

Satoshi Tomiyama, Moritaka Nagayama, Naoto Hamasaki, Satoshi Mori, Tomoaki Yoshikawa Fuminori Kanaya and Kunio Ibaraki

Department of Orthopaedic Surgery, University of the Ryukyus

Satoshi Nakasone

Okinawa Crippled Children's Hospital

\begin{abstract}
Bipolar hip arthroplasty for treatment of the rheumatoid hip with acetabular bone defects was performed on 14 joints in 10 cases. For acetabular reconstruction, bone graft alone was needed on 9 joints in 6 cases (BG group) and bone graft with hydroxyapatite granules was needed on 5 joints in 4 cases (HA group).

Radiological progression of migration of the outer head was examined in both groups by X-p films and compared.

Within 1 year after surgery central and upper migration of the outer head was larger in the HA than in the BG group. But, no significant progress was seen after the second post-operative year.
\end{abstract}

Key words : Rheumatoid Arthritis (慢性関節リウマチ), Bipolar Hip Arthroplasty (人工骨 頭置換術), Bone Graft (骨移植), Hydroxyapatite（水酸化アパタイト）

はじめに

私たちは曰蓋部の骨欠損を伴う慢性関節リウマチの 股関節に対して, 移植骨を臼蓋部に充填し補強した上 で bipolar 型人工骨頭置換術を行っている.しかし， 慢性関節リウマチにおける骨移植術の問題点として骨 萎縮のため単位体積あたり採取できる移植骨量がそし い上に骨移植を必要とする多関節手術を受けることが
多く，採骨量の制約を受けること，さらに術後移植骨 の圧壊吸収が生じることなどがある。これらの問題に 対応するため, 私たちは骨移植に水酸化アパタイト顆 粒を併用している.

今回, 臼蓋部骨欠損に対する補填法としての骨移植 単独群と水酸化アパタイト顆粒併用群について, 臼蓋 側のレ線所見の経時的変化を比較し, 水酸化アパタイ 卜顆粒の有用性を検討したので報告する. 


\section{対象および方法}

対象は, 術後 1 年以上を経過した RA 患者 10 例 14 股である. 骨移植単独群（以下単独群）は 6 例 9 股, 全例女性, 手術時年齢は平均 59 歳, 術後追跡期間は 平均 3 年 8 カ月であった. 水酸化アパタイト顆粒併用 群（以後 $\mathrm{HA}$ 群）は 4 例 5 股, 男 1 例女 3 例, 手術 時年齢は平均 43 歳, 術後追跡期間は平均 2 年 1 力月 であった。

臼蓋部骨移植法は, 単独群では腸骨および切除骨頭 をブロックあるいはチップとして臼蓋底部と荷重部に 移植した. HA 群では, 切除骨頭より作製したチップ に大きさ約 $3 \sim 5 \mathrm{~mm}$ の不定形の水酸化アパタイト 顆粒（ボーンセラムP） $5 \mathrm{~g} \sim 10 \mathrm{~g}$ を混ぜ, さらにフィ ブリン糊を注入したのちに臼蓋部に移植し，Trial

\section{単独群}

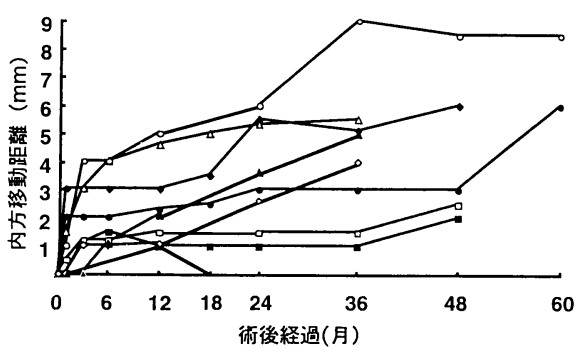

図 2 内方移動の推移

単独群 9 股では術後 1 年目までに $3 \mathrm{~mm}$ 以上移動したものは 3 股であり, 術後 1 年 目以降は 4 股で継時的に移動が進行し， $3 \mathrm{~mm}$ 以上の内方移動が認められた. 一方, $\mathrm{HA}$ 群は術後 1 年目までの内方移動は全例で $3 \mathrm{~mm}$ 以上であったが, 術後 1 年以降 2 年目までの内方移動の進行は全例で $3 \mathrm{~mm}$ 以下であった。
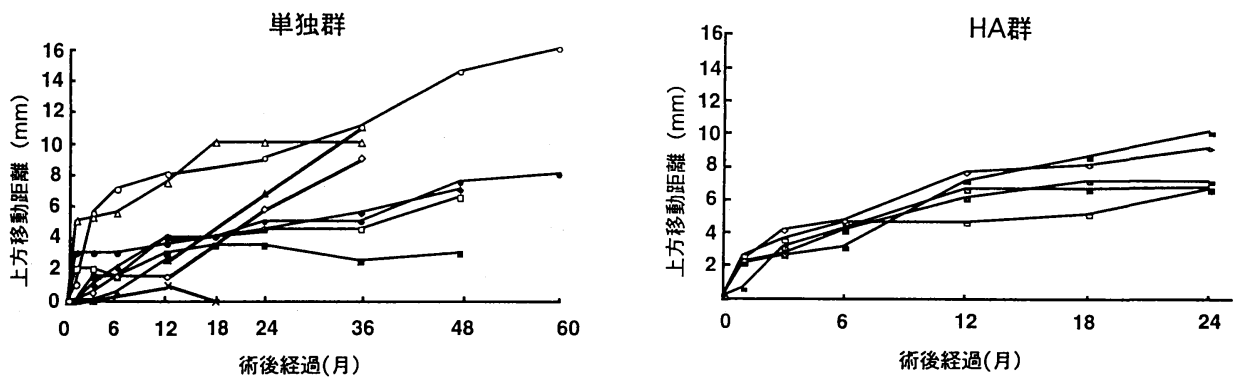

図 3 上方移動の推移

単独群では術後 1 年目までに $3 \mathrm{~mm}$ 以上移動したものは 6 股であり, 術後 1 年目以 降は 5 股で継時的に移動が進行し, $3 \mathrm{~mm}$ 以上の上方移動が認められた. HA 群の 上方移動は, 内方移動と同様術後 1 年目までは全例で $3 \mathrm{~mm}$ 以上であったが, 術後 1 年以降 2 年目までの内方移動の進行は全例で $3 \mathrm{~mm}$ 以下であった. 
headを押し付けて形を整えた。使用した bipolar 型 人工骨頭は OMNIFIT あるいは OMNIFLEX であっ た。

評価方法は, 単純レ線像で outer head の移動を観 察した。図1に示すようにKöhler 線から outer head 内側までの最短距離の減少を内方移動, 両涙痕 を結んだ線から outer headの頂点までの距離の増加 を上方移動として表した。

結果

Outer head の内方移動は, 単独群 9 股では術後 1 年目までに $3 \mathrm{~mm}$ 以上移動したものは 3 股であり,
術後 1 年目以降は 4 股で継時的に移動が進行し, $3 \mathrm{~mm}$ 以上の内方移動が認められた。一方, HA 群 5 股では 術後 1 年目までの内方移動は全例で $3 \mathrm{~mm}$ 以上であっ たが, その後内方移動はさほど進行せず, 術後 1 年以 降 2 年目までの内方移動は全例で $3 \mathrm{~mm}$ 以下であっ た（図 2 ).

Outer head の上方移動は, 単独群では術後 1 年目 までに $3 \mathrm{~mm}$ 以上移動したものは 6 股であり，術後 1 年目以降は 5 股で継時的に移動が進行し， $3 \mathrm{~mm}$ 以上の上方移動が認められた。 HA 群の上方移動は, 内方移動と同様術後 1 年目までは全例で $3 \mathrm{~mm}$ 以上 であったが, 術後 1 年以降 2 年目までの内方移動の

\section{内方移動の比較}

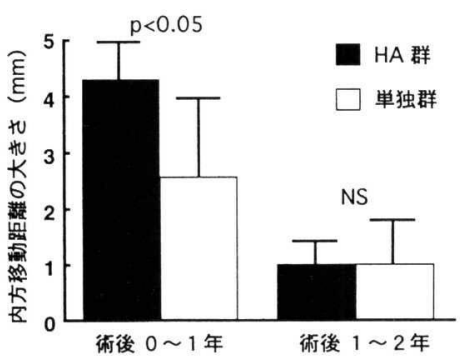

\section{上方移動の比較}

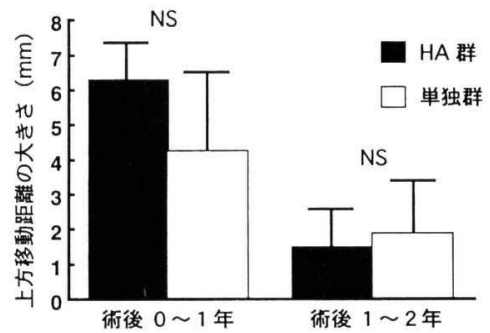

図 4 両群間における術後 $0 \sim 1$ 年および術後 $1 \sim 2$ 年の移動距離 の比較

術後 0 ～ 1 年の内方移動の大きさは単独群に比べ HA 群が 有意に大きかったが, 術後 1 ～ 2 年では内方移動に有意差は なかった. 上方移動は術後 $0 \sim 1$ 年および術後 $1 \sim 2$ 年にお いて有意差はみられなかった。

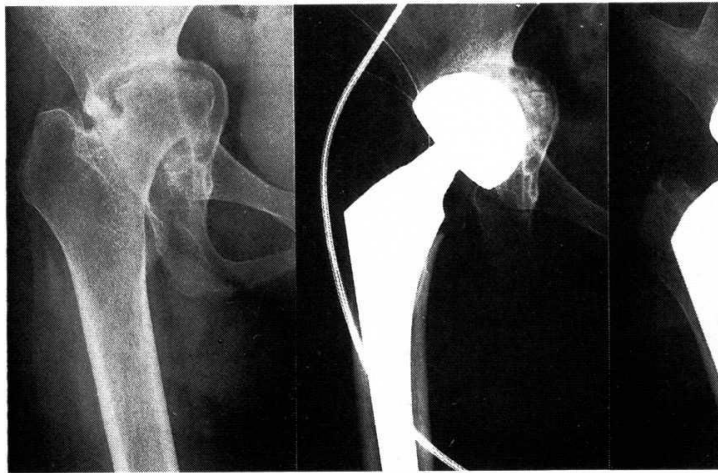

術前
術直後

四
骨移植単独例 39 歳 女性

$\begin{array}{lll}\text { 内方移動 } & 1 \mathrm{~mm} & 2 \mathrm{~mm} \\ \text { 上方移動 } & 3 \mathrm{~mm} & 3 \mathrm{~mm}\end{array}$




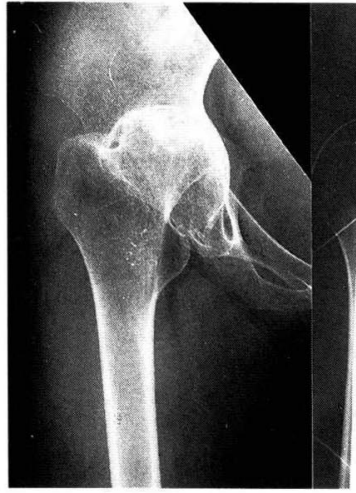

術前

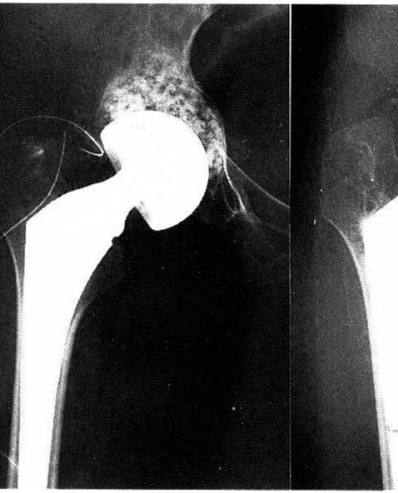

術直後

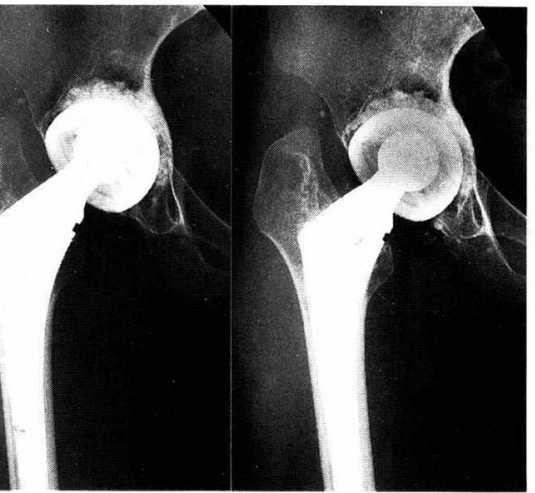

術後 1 年

術後 2 年

図 6 HA 併用例 26歳 女性

$$
\begin{array}{rrr} 
& \text { 術後 1 年 } & \text { 術後 } 4 \text { 年 } \\
\text { 内方移動 } & 3.5 \mathrm{~mm} & 4.5 \mathrm{~mm} \\
\text { 上方移動 } & 6.5 \mathrm{~mm} & 6.5 \mathrm{~mm}
\end{array}
$$

進行は全例で $3 \mathrm{~mm}$ 以下であった（図 3 ）.

両群間で術後 1 年目までの内方拉よび上方移動の大 きさと, 術後 1 年目から 2 年目までの 1 年間の移動の 大きさを比較した. 内方移動の進行は, 術後 1 年目ま では有意にHA群が大きかった（ $\mathrm{P}<0.005)$ 。一方， 術後 1 年目から 2 年目までの 1 年間の移動に有意差は なかった. 術後 1 年目における上方移動の大きさは HA 群が大きい傾向があったが有意差はなく, 術後 1 年目から 2 年目までの 1 年間の移動の大きさには有意 差はなかった（図 4 ).

代表症例を示す。骨移植単独例。39歳, 女性, 腸 骨と摘出骨頭を用いて臼底部を補強し， bipolar 型人 工骨頭置換術を施行した. 術後, 移植骨は均一化し不 鮮明化するとともに術後 1 年目までに内方移動が 1 $\mathrm{mm}$, 上方移動が $3 \mathrm{~mm}$ と軽度の outer head の移 動を認めたが, 術後 1 年目以降 4 年目の現在までは移 動はほとんど進行していない（図 5 ). HA 併用例, 26 歳女性, 摘出骨頭を chip とし, ボーンセラム P 10 $\mathrm{g}$ を混ぜて白底部に移植した. 術直後より術後 1 年目 までレ線上水酸化アパタイト顆粒は圧縮され均一化す るとともに outer head の内方移動が $3.5 \mathrm{~mm}$, 上方 移動が $6.5 \mathrm{~mm}$ みられたが, 術後 1 年目以降は骨頭周 辺の硬化像が強くなり, 2 年目の現在まで, outer head の移動は進行していない（図6).
考

察

骨萎縮があり臼蓋部骨欠損を伴った慢性関節りウマ 千の股関節の再建は困難を極める。このような症例に 対し曰蓋部骨移植を併用した bipolar 型人工骨頭置 換術を行うと, 荷重歩行開始に伴い移植骨間の咬み込 みや移植骨の collapse, あるいは血行再建に伴う 骨吸収のため outer headの migration を生じるこ とが大きな問題となっている。これに対し，種々の骨 移植法による臼蓋部再建術が試みられている1/2)4/5). 近年移植骨量を補うためバイオアクティブセラミック ス, 中でも水酸化アパタイトの臨床への応用が急増し

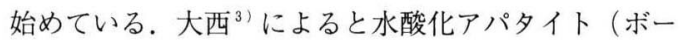
ンセラムP）は骨充填材として強度に優れ, 取扱いが 容易であり, さらに生体内では骨伝導能を有し, 異物 反応がなく, 吸収されにくいなどの優れた特徵をもっ ている。このような理由から私たちは骨移植に水酸化 アパタイト顆粒を併用している.

今回, 術後レ線上の経過から, HA 群の術後 1 年以 内の migration が大きかったことの原因として, 使 用した水酸化アパタイト顆粒間あるいは移植骨と水酸 化アパタイト顆粒間のすきまが荷重開始後に縮小して きたため容積が減少したことが考えられる。一方, 術 後 1 年以降は migration が小さかったことから, 術 後一年以降は水酸化アパタイト顆粒が圧縮均一化し, 容積減少が殆ど進行しなかったと考えられる. 
大西は, THR の再置換術の際に臼底骨欠損部へ水 酸化アパタイトの顆粒を充分につめ込めば術後容積の 減少は生じないと報告している，したがって，大きさ の異なる顆粒を混合することにより水酸化アパタイト 顆粒の充填率を高めれば術後早期の容積隇少を防止す ることが可能と考える.

今後さらに経過観察を行い, 骨移植における水酸化 アパタイト顆粒併用の長期成績を検討していきたい.

$$
\text { ま と め }
$$

(1)臼蓋部骨欠損を伴った慢性関節リウマチの骨欠損 に対する補填法として行った骨移植単独群と水酸化ア パタイト顆粒併用群について，臼蓋側のレ線所見の経 時的変化を比較，検討した。

(2)水酸化アパタイト顆粒併用群は骨移植単独群に較
べ術後 1 年以内は outer head の内方移動, 上方移動 とも大きい傾向があった. しかし, 術後 1 年以降 2 年 目までの内方移動および上方移動の進行は両群間で有 意差はなかった。

\section{参 考 文 献}

1）森田秀穂ら：慢性関節リウマチによる因底突出症に対 する再建術について. 日関外誌, $7: 263-272,1988$.

2）仲宗根聡ら：慢性関節リウマチに対する bipolar 型人 工骨頭置換術の経験。 日関外誌, $9: 327-332,1990$.

3）大西啓靖：ハイドロキシアパタイトを応用した人工関 節の再手術-再置換。別冊整形外科, $16: 100-107,1989$.

4）鳥巣岳彦ら：骨欠損が著明な高度破壊の股関節に対す る再建手術の問題点. 日関外誌, $9: 333-340,1990$.

5）鳥巣岳彦：慢性関節リウマチに対する bipolar 型人工 骨頭置換術. Orthopaedics, 3 :73-80, 1988. 